\title{
CURTAINS UP!
}

\section{Shifting Emotional Styles in Gay Men's Venues Since the 1950s}

\author{
Benno Gammerl
}

\begin{abstract}
This opinion piece enquires into the history of male homosexuality in West Germany since the 1950s and focuses on the transition from the homophile bar to the gay disco as a prototypical meeting place for same-sex desiring men. Which emotional shifts did this spatial variation entail? Based on oral history interviews and gay magazines, the analysis explores intricate changes in queer everyday life beyond the all too simple supposition that closeted shame was supplanted by openly gay pride. In addition, the study shows on a methodological level that the allegedly antagonistic approaches in emotion research - constructionism, praxeology, affect-theory and phenomenology - can actually be fruitfully combined with each other, especially when it comes to analysing the interplay between spaces and feelings.
\end{abstract}

Spaces shape feelings, feelings shape spaces. This is, in a nutshell, the argument this opinion piece puts forward. From a history of homosexualities perspective, this implies that looking at emotional changes is crucial, when we want to fully grasp the complexities of how the lives of same-sex desiring people have changed across time. From a history of emotions perspective, it also means: If we want to understand changes in emotional patterns and practices, then looking at shifting spatial constellations is a particularly fruitful endeavour.

\section{Divergent approaches in research on emotions and spaces}

Four major approaches inform research on feelings in general and on the interaction between feelings and spaces in particular. Firstly, perspectives highlighting the social construction of feelings emphasise 'emotional standards', 'communities' or 'regimes' (Stearns and Stenrs 1985; Reddy 2001; Rosenwein 2006). They focus on codes and conventions and are particularly influential within the history of emotions. Yet their emphasis on social rules tends to lose sight of non-conforming feelings and of the often confusing nature of emotional everyday life. Praxeological
Benno Gammerl 
approaches, secondly, focus on 'emotional practices' or 'habitus' instead (Scheer 2012; Eitler and Scheer 2009). They are better equipped to grasp these ambivalences, as they allow for the possibility of failure involved in each emotional performance. But by and large they also highlight the reproduction of certain patterns, thereby eliding the possibility of unexpected and unintelligible feelings. This is exactly where, thirdly, approaches inspired by affect theory prove their strength (Massumi 2002; see also Hutta 2015). They emphasise the non-representational and excessive dimensions of feelings that do not conform to pre-set rules and meanings. But in doing so they sometimes lose sight of the ways in which political and economic conditions shape and limit the affective potentials specific actors can mobilise. In another register, phenomenological approaches, fourthly, also de-emphasise cultural and historical specificities and try to formulate universally valid assumptions about feelings instead (Schmitz 1992; Patočka 1998).

Each of these approaches suggests a particular way of analysing the interaction between spaces and feelings. Social constructionist approaches claim that different emotional standards prevail in distinct places like the beach and the office (Gammerl 2012). Praxeology pinpoints instead how spaces and actors performatively co-constitute each other (Reckwitz 2012). Specific spatial constellations thus facilitate certain emotional practices that in turn inform the ways in which people handle these very settings. Affect theory highlights that encounters between bodies in space engender feelings which exceed clear-cut societal frameworks and subjective interpretations (Thrift 2007). Also, phenomenology finally considers spatial atmospheres as engulfing and overwhelming the subject (Böhme 2006; Tuan 1974). Within research on feelings these approaches are often depicted as mutually exclusive or even as antagonistic. Yet ultimately it is, as this opinion piece argues, much more productive to combine them. The analysis can thus profit from the specific potentials each of them holds, while avoiding their particular pitfalls. Proving this point is the theoretical and methodological aim this text sets out to achieve.

\section{Spatial emotions and emotional spaces in the history of homosexualities}

Empirically, my focus is on the history of male homosexuality in West Germany since the 1950s. Suppositions about spatial emotions and emotional spaces are at the core of the narrative that dominates widespread Western understandings of how the situation of same-sex desiring people changed in the second half of the twentieth century. According to the prevailing assumption, this period witnessed a process of liberation that led gays and lesbians out of their shameful closet into the light of proud visibility (Grumbach 1997; on the (West) German history of homosexualities in general see Gammerl 2010; Kraushaar 1997). Such narratives have been criticised from various perspectives (see Köppert and Regener 2013; Sedgwick 1990). Were same-sex loving men and women really invisible in the post-war decades? Did they move, as a famous slogan had it, "out of the toilets into the streets" in the 1970s? And was this transition actually linked with an emotional shift that replaced shame and fear with pride and self-assertion?

These questions show that issues of space and emotion are at the core of the contemporary history of homosexualities. Therefore, it is rather surprising that there is comparably little research on how the meeting places of men loving men have changed since the 1950s and what kinds of emotional patterns and practices these shifting settings entailed (for geographical research on these questions see Johnston and Longhurst 2010; Binnie and Valentine 1999). Both questions are addressed by the empirical study this opinion piece pursues. It is based on materials that I analyse within my current research project on homosexuality and emotional life 
between urban and rural contexts in West Germany from 1960 to $1990 .{ }^{1}$ These comprise gay and lesbian publications as well as 32 interviews with men loving men and women loving women born between 1935 and 1970. For exploring the complexity of specific locales and the intricacies of emotional change these oral history sources have proven particularly valuable (Gammerl 2015). As this opinion piece cannot possibly do justice to this wealth of detail when trying to cover all the different spaces where men loving men met each other, it focuses on one paradigmatic shift, namely that from the homophile bar to the gay disco.

\section{The homophile bar: a theatre of cautious gazes}

The homophile bar was one of the typical meeting spaces for same-sex desiring men in the first post-war decades (on the bar culture of the 1950s and 1960s see Whisnant 2012, 133-65; Wolfert 2009, 105-10 and 154-60; Meeker 2001). Figure 1 shows such a venue. The photograph accompanied an advertisement for the Café de Paris in West Berlin which specifically highlighted the "comfortable chairs with yellow floral design covers", the "heavy curtains combined with pretty cloud-drapes", the "precious mirrors", the "polished brass dance floor" and the fact that the owners ensured "at the door" for an appropriate "selection of guests" (Anon. 1970). ${ }^{2}$

These so carefully described interior design and other details are somewhat reflected in a passage from the interview with Mr. Meyer who was born in 1944. He describes his visit of a homophile bar in the late 1960s with the following words:

1 See https://www.mpib-berlin.mpg.de/de/forschung/geschichte-der-gefuehle/ projekt-anders-fuehlen/die-studie-und-erste-ergebnisse (7 March 2017).

$2 D u \&$ Ich 1970, 2(4):16. Du \& Ich was published from 1969 to 2014 mostly in Hannover and was one of the most widespread gay magazines in West Germany. All translations from German sources are by the author.
We stood in front of some bar, $[\ldots]$ and one could not just enter like this, one had to ring a bell. [...] someone peeked, probably for sure, from the inside through the spy hole and opened the door. Yes, we entered this somewhat all chintz and fluff, er, (.) room with reddish furniture and decoration, and I had the feeling, everybody is looking at you now. (pause) [...] luckily I was not alone, but this Hans was also there. That means, I did not have to sink into the ground at once somewhere. It was really, I could have a little conversation with him and, er, er, direct my gaze at him, just as you do when you talk, but I could also cautiously look around, like this, yes, what I later on found so exciiiting, Mr. Gammerl. FLIRTING, I thought that, that, th-th,

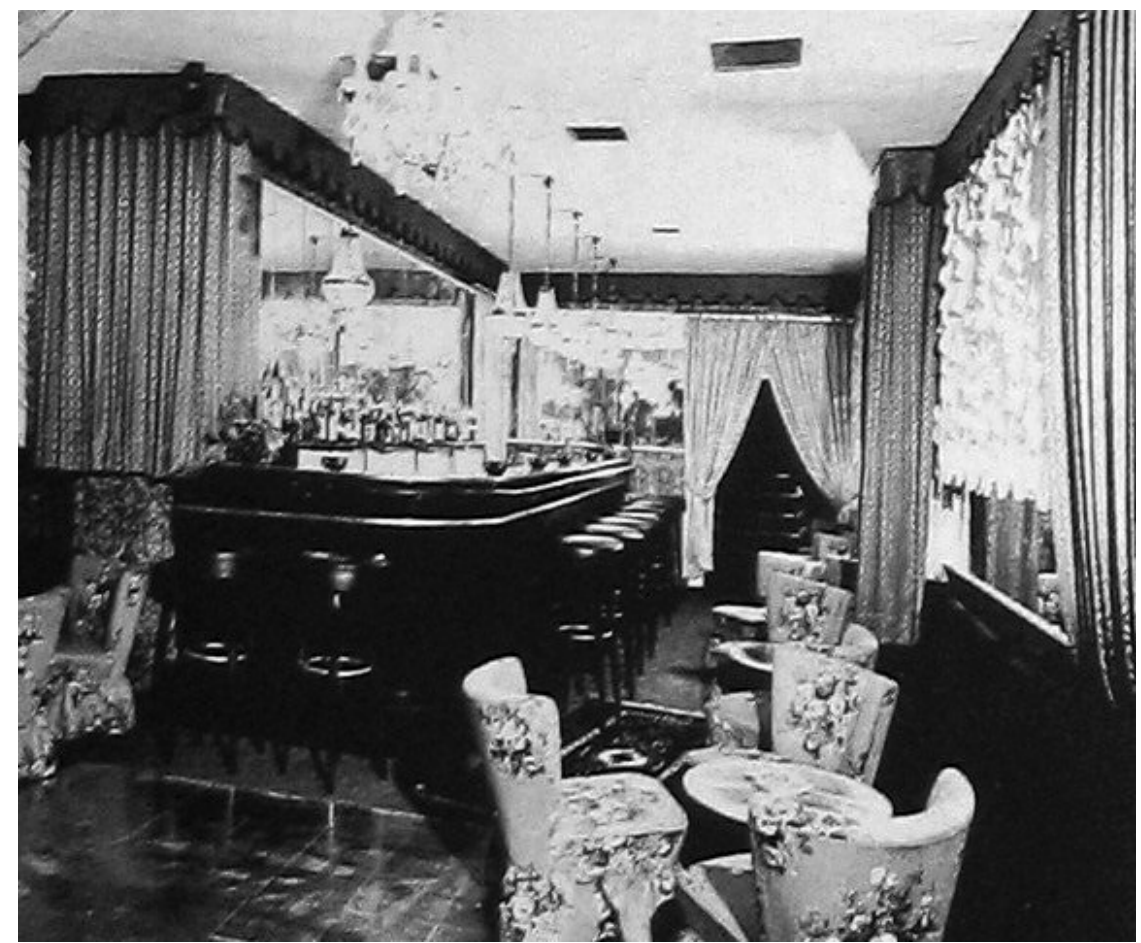

Figure 1: The decorous interior of a homophile bar, from $D u$ \& Ich 1970, 2(4):16.
SQS

$1-2 / 2016$

59

Queer/

View/Mirror

Opinion

Piece

Benno Gammerl 
flirting with MEN, that, well, I really did like that a lot, indeed. It is all, if people are chatting online today, they completely miss out on that beautiful foreplay. They pick one another, $[\ldots]$ but this, erm, getting to know someone or batting one's eyelids and there was the routine of treating others. Like, the landlord then says, that is from THIS gentleman back there, that is for YOU. And then somebody sat there and did then a little (in a low voice) very cautiously, er, like this. (laughs) Mr. Gammerl, that, yes, that was then, (.) er, yes, that was in the late $60 \mathrm{s.}^{3}$

The first things that draw attention are the spy hole and the bell. Together with the curtains that many other interviewees from Mr. Meyer's generation mention these devices tried to protect men loving men from external dangers and allowed them to hide in a secluded space. As consensual sex between adult men was illegal in West Germany until 1969, the need for such measures was quite obvious. Yet by guarding patrons against the gazes of passers-by, the curtains and closed doors also implied the logic of shame. One wanted to avoid being seen. This focus on the gaze continued inside the bar as well. Mr. Meyer who had already been eyed up before he entered the venue felt even more like a looked at object once inside. He himself was also largely concerned with where he could and should direct his gaze. Once more this implied the ashamed wish to sink into the ground. But it afforded the joyous excitement of flirting as well: eye contact, roaming and lingering gazes, batting eyelids and gestures which were just about perceivable.

3 Mr. Meyer, int. 1, seq. 139. I conducted two interviews (int.) with every respondent. The sequence numbers (seq.) count consecutively through the transcript of both conversations, with every change of speaker marking the beginning of a new sequence. All interviewees' names are pseudonyms. Capital letters mark an emphasis.
All of this was, if not entirely enabled, at least tremendously enhanced by the spatial setting of homophile bars like Café de Paris. The space was compartmentalised in a way that allowed eyes to wander around, it had corners for hiding and exposed places for presenting oneself, and it had mirrors that extended the reach of flirting gazes. In short, these bars afforded large scopes for manoeuvres between closeness and distance. Accepting an invitation from the gentlemen 'back there' was one way to play this game. Another arena was the dance floor where partners got closer to each other while trying to keep their distance from other couples. These practices and these environments thus allowed for cautiously creating intimacy between men.

\section{The gay disco: in the jungle of moving bodies}

Disco that came to shape West German gay scenes in the course of the 1970 s and 1980s created a completely different situation (on gay disco see Lawrence 2006; on the queer history of this period see Griffiths 2016; Pretzel and Weiß 2012).

The image on the next page (see figure 2, p. 61) accompanied a report on gay disco venues in West Germany and allows for a blurred glimpse into the period's gay night-life (Bülow 1989). Back then 'disco' was very popular all over the place, but especially among men desiring men. Some differences between Figures 1 and 2 are obvious. Firstly, it is most significant that the homophile bar was presented as empty, foregrounding its spatial structure, while the gay disco was depicted as packed, focusing on the dancing crowd instead. This crowd was, secondly, not ordered according to any pattern. The fact that there were no apparent couples on the dance floor also contributed to this disarrangement. Many of my respondents emphasise that the practice of two men dancing together 


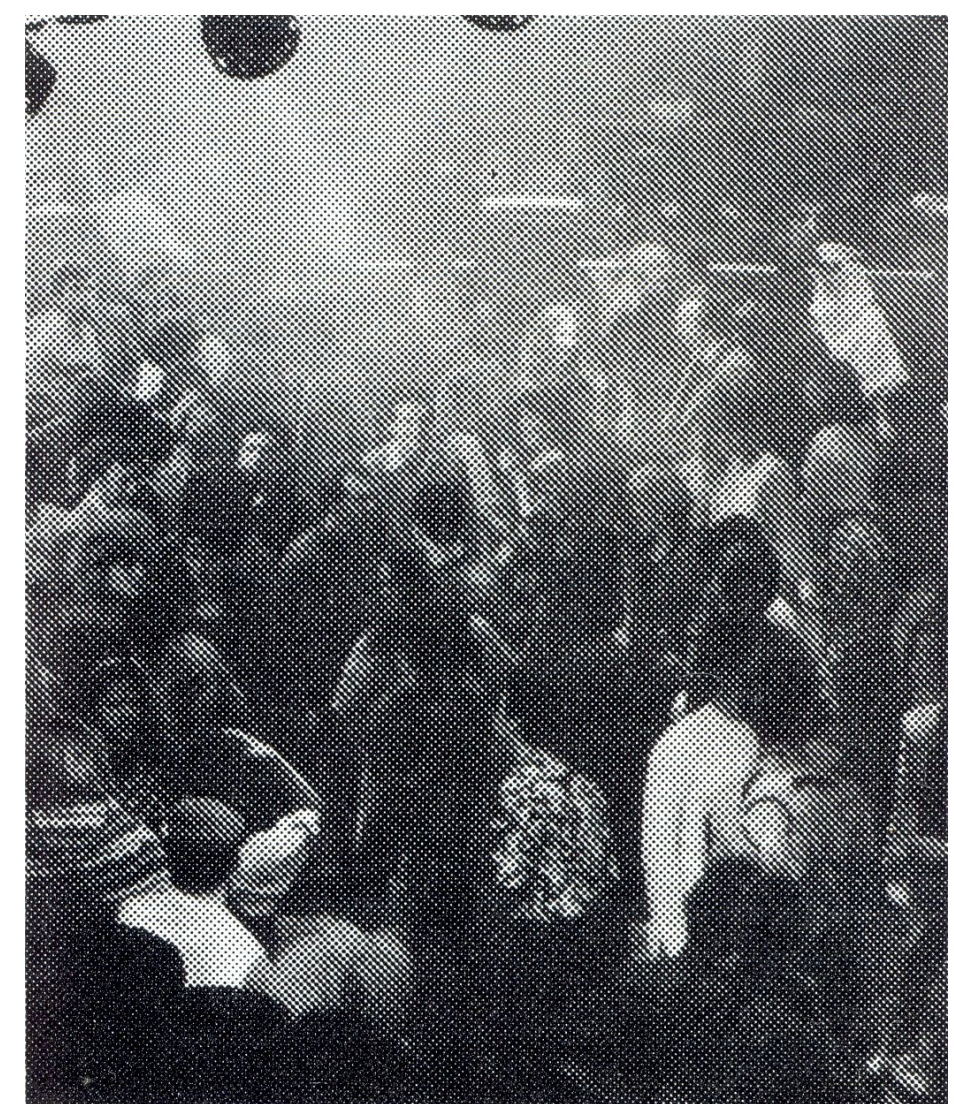

Figure 2: The raucous crowd in a gay disco, from $D u$ \& Ich 1989, 21(7): 3 .

hardly survived the 1970s. Therefore, the crowd's movements seem chaotic. This irregularity corresponded, thirdly, to a spatial setting that featured a large open space where everyone moved on the same level. In contrast to the homophile bar, the gay disco thus afforded an environment that enhanced the likelihood of chance bodily contact.

This likelihood was further increased by the fact that access to the gay disco was less restrictively controlled than in most homophile bars. In
1984 the Unabhängige Homosexuelle Alternative Hamburg organized a "Gay Night" which, as a report claimed, was "totally disco" and which actually took place in the cafeteria of the local university (W. 1985). The door policy enforced there was certainly less strict than the one of the Café de Paris. In this vein, many sources highlight that curtains, spy holes and bells which had turned homophile bars into secluded spaces, disappeared in the course of the 1970s, giving way to shop windows that allowed passers-by to look inside and to open doors that allowed them to enter if they wished. This was also indicative of a new emotional style gaining currency among gay men in the 1970s. If they were not proud of, they were at least not ashamed enough about their sexual orientation to hide themselves when meeting other men.

But the emotional space of the gay disco encompassed other feelings as well. A passage from Mr. Pohl's narrative demonstrates this. He was born in 1956 and in the late 1970s he paid regular visits to a disco that he describes as his "navel of the world".

Here was true, vibrant life. When I visited for the first time, I still remember, it was such a disco, relatively spacious, $[\ldots]$ there were easily like 100, 100 gays in this space later on, dancing, great music, fantastic atmosphere, super marvelous $[. .$.$] and I thought: that's$ absolutely fabulous here. (.) I felt it was like a window opening up for me $[\ldots]$ and I thought: amazing that there is so many gay men [... ] suddenly one had like a GROUP, $[\ldots]$ a feeling of belonging. (Mr. Pohl, int. 1, seq. 176)

Mr. Pohl mentions a number of spatial particularities here that engendered specific feelings. First, he highlights the openness - also hinted at by the metaphor of a window opening up - and the size of the room. Second, he refers to a crowd too large to count it, thus evoking that the place was packed. Third, he emphasises the rhythmical corporeality of the atmosphere. Mr. 
Pohl speaks of a "pulsating" vibrancy and uses the German-English word "abhotten" to characterise the way in which people danced. All of this adds up to a synesthetic experience that combined visual and olfactory perceptions, soundscapes, temperatures and the joint, though unorganised moving of the crowd. This environment engendered in Mr. Pohl a feeling of belonging that significantly differed from the sense of security and affiliation that the homophile bars had generated. Within this new setting a 'back there' from whence a generous gentleman could cautiously greet did not exist any longer. In the disco, another one of my interviewees says, one rather moved "just like that between so many beautiful guys". ${ }^{4}$ The disco setting thus enabled coincidental contact that made it difficult to ascertain who was touching whom. Within the multitude of bodies moving towards and past each other gazes and touches no longer sent clear-cut messages that obliged those emitting them to certain consecutive actions. The dynamics of getting closer and the fabrication of intimacy between men therefore implied completely different patterns and practices in the gay disco than they had done in the homophile bar.

\section{Conclusion}

In spite of its brevity and sketchiness, this analysis allows for two further reaching conclusions. Firstly, on methodological and theoretical levels, it shows that allegedly antagonistic approaches to the interaction between emotions and spaces can be fruitfully combined. In this vein, this opinion piece relied on the social constructionist claim that different standards prevail in distinct places which informs the crucial finding about the specific emotional styles stipulated and employed in bars and gay discos

4 Mr. Ückert, int. 1, seq. 351. Mr. Ückert was born in 1945. respectively. At the same time it picked up on praxeological approaches when it found that specific spatial constellations facilitated certain emotional practices. By way of this dynamic the interior design of homophile bars with curtains, spy holes, mirrors, tables, et cetera enabled particular practices of shaming and flirting. The study, moreover, also employed concepts inspired by affect theory when it claimed that encounters between bodies on the disco dance floor enabled intimate moments that did not carry any clear-cut meaning, but rather unfolded open-ended emotional potentials. And it finally brought phenomenological notions of overwhelming atmospheres into play when it highlighted the unavoidability with which the synesthetic experience of the gay disco absorbed Mr. Pohl. While these observations merely hint at the possibility of theoretically integrating the divergent approaches, they certainly demonstrate that analysing spatial emotions and emotional spaces offers a particularly promising path for this endeavour and for establishing a common ground for constructionist, praxeological, affect-theoretical and phenomenological approaches on which their respective assets can be fruitfully combined and make good for the shortcomings each of them entails.

Secondly, on an empirical level, the analysis provides the history of sexualities with exciting vistas into the everyday lives of same-sex desiring men. Moving beyond the generalising assumption that all gay men have since the 1950s left their closets and entered the light of public visibility, the enquiry registered manifold changes in the spatial arrangements of the places where men loving men met. Curtains did in fact disappear, but the claim that utter seclusion was replaced by total openness does not adequately and comprehensively describe the shift. Apart from changes in how the boundary between outside and inside was marked and maintained, the gay disco also devised completely different interior settings that enabled new practices for becoming intimate. While patrons of homophile bars had primarily relied on gazes to cautiously manoeuvre between closeness and 
distance, the gay disco facilitated non-committal encounters initiated by (seemingly) accidental bodily contact.

Besides highlighting these more intricate ramifications of the divergent spatial settings, it is also crucial to point out that bars were not completely supplanted by discos in the 1970s and 1980s. This period rather witnessed a diversification of spaces where men loving men could meet and live out their emotions in a variety of ways. Bars and discos came to be available alongside each other and further places like saunas, community centres and cruising areas in public parks where same-sex desiring men could encounter each other (Gammerl 2013). This proliferation of arenas had at least two decisive effects: First, it helped diversify the images of gay men circulating in public discourse and thus delegitimised pejorative and discriminating stereotypes. Second, it also increased the number of entry points through which individuals could access the gay community which made it easier and less scary for newcomers to join the scene. Both processes contributed to the liberation, normalisation and emancipation of same-sex love and desire.

Yet the supplementation of homophile bars by gay discos also involved emotional consequences that escape the all too simple and straightforward supposition that shame was supplanted by pride. On the one hand, the homophile practice of circumspective looking involved much more than an ashamed lowering of the gaze. It also, as Mr. Meyer stresses, enabled the joyous excitement of flirting. On the other hand, the chance bodily encounters the disco dance floor afforded did certainly not eliminate the possibility of shame-like experiences, especially not for those who found it difficult to adapt to the new emotional style of self-assertion. In this vein, the gay disco - besides breeding openness and spontaneity - also furthered a specific kind of shyness. Mr. Helmlinger, born in 1963, describes himself as "INCREDIBLY shy". "Contact with men", he says, "has always been very stressful" for him, because he never knew "what HAPPENS if I get close to someone". When he visited discos and other gay venues he was therefore "SHIVERING with insecurity", trying to hide his "weakness" and to maintain the outward appearance of a "cool bloke" who was casually watching the raucous crowd from the secure distance of an observer's position (Mr. Helmlinger, int. 1, seq. 12 and 134; int. 2, seq. 349). A more detailed enquiry into these ambiguous emotional ramifications of the gay disco might well prove a very rewarding future endeavour.

\section{References}

Anon. 1970. [Advertisement for Café de Paris], $D u$ \& Ich, April, 16.

Binnie, Jon, and Gill Valentine. 1999. "Geographies of Sexuality - a Review of Progress." Progress in Human Geography 23(2): 175-187. https://doi. org/10.1177/030913259902300202

Böhme, Gernot. 2006. Architektur und Atmosphäre. München: Fink.

Bülow, Thorsten D. 1989. "Der Disco Test," Du \& Ich, July, 3 and 14-16.

Eitler, Pascal, and Monique Scheer. 2009. "Emotionengeschichte als Körpergeschichte: eine heuristische Perspektive auf religiöse Konversionen im 19. und 20. Jahrhundert." Geschichte und Gesellschaft 35(2): 282-313. https://doi.org/10.13109/gege.2009.35.2.282

Gammerl, Benno. 2010. "Eine Regenbogengeschichte." Aus Politik und Zeitgeschichte 60(15): 7-13.

Gammerl, Benno. 2012. "Emotional Styles. Concepts and Challenges." Rethinking History 16(2): 161-175. https://doi.org/10.1080/13642529.2 012.681189

Gammerl, Benno. 2013. "Same-Sex Intimacy in Transition." History of Emotions - Insights into Research, October 2013. Accessed 14 March. https://doi. org $/ 10.14280 / 08241.8$

Gammerl, Benno. 2015. "Can you Feel your Research Results? How to Deal with and Gain Insights from Emotions Generated during Oral History Interviews." In Methods of Exploring Emotions, edited by Helena Flam and Jochen Kleres, 153-162. London: Routledge.
SQS

$1-2 / 2016$

63

Queer/

View/Mirror

Opinion

Piece

Piece

Benno Benno
Gammerl 
Griffiths, Craig. 2016. "Sex, Shame and West German Gay Liberation.” German History 34(3): 445-467. https://doi.org/10.1093/gerhis/ghw033

Grumbach, Detlef. 1997. "Hundert Jahre Schwulenbewegung? Ein Blick zurück nach vorn.” In Was heißt hier schwul? Politik und Identitäten im Wandel, edited by Detlef Grumbach, 13-26. Hamburg: Männerschwarm.

Hutta, Jan S. 2015."The Affective Life of Semiotics." Geographica Helvetica 70(4): 295-309. https://doi.org/10.5194/gh-70-295-2015

Johnston, Lynda, and Robyn Longhurst. 2010. Space, Place and Sex. Geographies of Sexualities. Lanham: Rowman and Littlefield.

Köppert, Katrin, and Susanne Regener, eds. 2013. privat/öffentlich. Mediale Selbstentwürfe von Homosexualität. Vienna: Turia + Kant.

Kraushaar, Elmar, ed. 1997. Hundert Jahre schwul. Eine Revue. Berlin: Rowohlt.

Lawrence, Tim. 2006. “'I Want to See All My Friends At Once'. Arthur Russell and the Queering of Gay Disco.” Journal of Popular Music Studies 18(2): 144-166. https://doi.org/10.1111/j.1533-1598.2006.00086.x

Massumi, Brian. 2002. Parables for the Virtual: Movement, Affect, Sensation Durham: Duke University Press. https://doi.org/10.1215/9780822383574

Meeker, Martin. 2001. "Behind the Mask of Respectability. Reconsidering the Mattachine Society and Male Homophile Practice, 1950s and 1960s." Journal of the History of Sexuality 10(1): 78-116. https://doi.org/10.1353/ sex.2001.0015

Patočka, Jan. 1998. Body Community, Language, World. Translated by Erazim Kohák, edited by James Dodd. Chicago: Open Court.

Pretzel, Andreas, and Volker Weiß, eds. 2012. Rosa Radikale? Die Schwulenbewegung der 1970er Jahre. Hamburg: Männerschwarm.

Reckwitz, Andreas. 2012. "Affective Spaces: A Praxeological Outlook." Rethinking History 16(2): 241-258. https://doi.org/10.1080/13642529.2 012.681193

Reddy, William M. 2001. The Navigation of Feeling: A Framework for the History of Emotions. Cambridge: Cambridge University Press. https://doi. org/10.1017/CBO9780511512001

Rosenwein, Barbara H. 2006. Emotional Communities in the Early Middle Ages. Ithaca: Cornell University Press.

Scheer, Monique. 2012. "Are Emotions a Kind of Practice (and is That What Makes them Have a History)? A Bourdieuian Approach to Understanding Emotion." History and Theory 51(2): 193-220. https://doi.org/10.1111/ j.1468-2303.2012.00621.x
Schmitz, Hermann. 1992. Leib und Gefühl. Materialien zu einer philosophischen Therapeutik. 2nd edition. Paderborn: Junfermann.

Sedgwick, Eve Kosofsky. 1990. Epistemology of the Closet. Berkeley: University of California Press.

Stearns, Peter N., and Carol Z. Stearns. 1985. "Emotionology. Clarifying the History of Emotions and Emotional Standards." American Historical Review 90(4): 813-836. https://doi.org/10.2307/1858841

Thrift, Nigel. 2007. Non-representational Theory. Space, Politics, Affect. London: Routledge.

Tuan, Yi-Fu. 1974. Topophilia. A Study of Environmental Perception, Attitudes, and Values. New Jersey: Prentice Hall.

W. 1985. "Disco \& Show," Du \& Ich, January, 60.

Whisnant, Clayton J. 2012. Male Homosexuality in West Germany. Between persecution and Freedom, 1945-1969. Basingstoke: Palgrave.

Wolfert, Raimund. 2009. Gegen Einsamkeit und 'Einsiedelei'. Die Geschichte der Internationalen Homophilen Welt-Organisation. Hamburg: Männerschwarm.
SQS

$1-2 / 2016$

Queer/

View/Mirror

Opinion

Piece

Benno

Gammerl 